\title{
Effect of cigarette smoking on HDL-C in adolescent
}

\author{
Afrin $\mathrm{L}^{1}$, Rahman $\mathrm{MR}^{2}$, Hoque $\mathrm{MN}^{3}$, Amin $\mathrm{MR}^{4}$
}

\begin{abstract}
:
Objective: A case control study was carried out in the Department of Physiology in Dhaka Medical College during the period of January 2005 to December 2005 to evaluate the effect of smoking on serum HDL-C in adolescent male smokers. Method: Total 80 male subjects with age range 12-19 years were included in this study, out of them 60 were case and remaining 20 were age matched healthy nonsmoker control. Cases were divided into three subgroups on the basis of consumption of sticks per week [mild (Group-l) 1-19, moderate (Group-ll) 20 - 59 and heavy [(Group-Ill) 60)]. Serum HDL-C was measured and compared between case and control and among the subgroups of case. Unpaired-t test \& Bonferroni test were done to determine the significance level between the groups and among the subgroups respectively. Pearson's correlation test was performed to determine correlation coefficient and level of significance in case regarding serum HDL-C with number of stick consumption. Result: Mean \pm SD HDL-C level was $31.72 \pm 8.99 \mathrm{mg} / \mathrm{dL} \& 55.60 \pm 6.81 \mathrm{mg} / \mathrm{dL}$ in case \& control respectively. Serum HDL-C was significantly lower $(\mathrm{p}<0.001)$ in case than control. Mean \pm SD HDL-C level in the subgroups were $33.95 \pm 8.77 \mathrm{mg} / \mathrm{dl}, 31.50 \pm 8.22$ \& 29.70 \pm 9.84 . But no statistically significant difference was observed among the subgroups. Negative correlation was observed between serum HDL-C with number of stick consumption.

Conclusion: From the study it can be concluded that cigarette smoking in adolescent is associated with low level of cardio protective lipoprotein HDL-C and low trend is related with increased consumption of cigarette, which might lead to occurrence of several coronary artery diseases.
\end{abstract}

\section{Introduction:}

Smoking is considered as an important factor in the stimulation of the development of atherosclerosis and cardiovascular diseases and it is one of the main avoidable causes of death in the world ${ }^{1}$.

Smoking is most likely to begin during adolescence and it is commonly reported that children smoke their first cigarette while attending primary school. In developed countries there are more female than male smokers among adolescents while the rates of smoking initiation are also higher for female but in most developing countries there is still a higher prevalence of male smokers ${ }^{2}$.

It has been observed that start of even modest cigarette smoking during adolescence and early adulthood adversely alters the serum lipid and lipoprotein levels ${ }^{3-}$ ${ }^{5}$. Several studies also have shown that there is a dose response relationship between the numbers of cigarette smoked and change in serum lipid and lipoprotein levels ${ }^{4-12}$.

Nicotine, which is one of the major components of cigarette may increase the risk of atherosclerotic vascular disease by affecting lipid metabolism, coagulation, hemodynamic status, or all three ${ }^{3,14}$.
Lee et al. and Sirisali et al. suggested that nicotine, which is the main pharmacologically active component of cigarette, stimulates sympathetic nerve activity and causes release of catecholamines leading to lypolysis, which increases the plasma concentration of free fatty acids and decreases plasma HDL cholesterol fraction ${ }^{10}$.

Lipid and lipoprotein studies generally emphasize positive relationship of total cholesterol, low density lipoprotein cholesterol (LDL-C), very low density lipoprotein (VLDL) and triglyceride to the risk of coronary heart disease. The higher the concentration of any one of these blood lipids, the greater the risk of coronary heart disease. On the other hand, the high density lipoprotein cholesterol (HDL-C) appears to have an inverse relation to the risk of coronary heart disease, the lower their concentration the greater the risk of coronary heart disease ${ }^{15}$. Kavey observed that, HDL-C levels decrease significantly with exposure to cigarette smoking ${ }^{16}$. Similarly, Morrison et al., Orchard et al., Freedman et at., Craig et at., and Ghannem et at. also observed a lower HDL-C level in adolescent cigarette smokers ${ }^{1,4,5}$. Cigarette smoking is a common problem in Bangladesh and also a major public health problem associated with morbidity and mortality. The prevalence of cigarette smoking has peaked among high school students. Although many works have been done relating smoking and HDL-C levels, those were mainly done on adult subjects and no such work has yet 
been carried out among adolescent male smokers in our country. So, the present study has beenAfrin , Rahman, Hoque, Amin et al. undertaken to know the effect of cigarette smoking on HDL-C level in adolescent male smokers.

\section{Methods:}

This case-control study was conducted in the Department of Physiology of Dhaka Medical College during the period of January 2005 to December 2005. Total 80 adolescent male, age ranged from 12-19 years were selected. Out of them 60 were smoker designated as case and 20 were age matched healthy nonsmoker subjects designated as control. The case group was again divided into three subgroups namely group I, II and III on the basis of cigarette consumption per week. Subjects who smoked 1-19 cigarettes per week were taken as group I (mild). Who smoked 20-59 per week and more than or equal to 60 per week were considered as group II (moderate) and III (heavy) respectively. All the subjects were selected on the basis of predetermined inclusion and exclusion criteria. Subjects who had smoked for at least one year, were free of certain diseases like diabetes mellitus, nephritic syndrome, thyroid disorder and had no history of taking lipid lowering drugs were considered as case group. Control subjects were selected who had never smoked and free of diseases or had no history of taking drugs which could affect lipid metabolism. After explaining the nature and benefit of the study, possible health hazard, written consent were taken from each of the participating study subject. Relevant history and clinical findings were recorded in a preformed data sheet. With all aseptic precautions $5 \mathrm{ml}$ venous blood was collected from the study subjects after 12 hours of fast. Serum was collected from the clotted blood after centrifugation. Serum HDL-C was measured by chemistry auto analyzer (Hitachi 9002). Data were expressed as mean \pm SD and analyzed by SPSS version 12.0 for windows. Unpaired t-test and Bonferroni test were done to determine the level of significance. To determine correlation coefficient and level of significance Pearson's correlation test was done.

Results: All the study subjects were male adolescent of same social class. Table-l shows the age and BMI distribution of case and control. No statistically significant difference $(\mathrm{p}>0.05)$ was observed regarding any of the above mentioned variables.
Table-l: Mean \pm SD of Age \& BMI of case \& control

\begin{tabular}{|l|l|l|l|l|}
\hline Variable & Case $(\mathrm{n}=60)$ & $\begin{array}{l}\text { Control } \\
(\mathrm{n}=2 \mathrm{n})\end{array}$ & t- value & $\mathrm{p}$ value \\
\hline $\begin{array}{l}\text { Age } \\
(\text { years })\end{array}$ & $\begin{array}{l}16.821 \pm 1.75 \\
(12-19)\end{array}$ & $\begin{array}{l}16.35 \pm 1.98 \\
(12-19)\end{array}$ & 0.99 & $>0.05$ \\
\hline $\begin{array}{l}\mathrm{BMI} \\
(\mathrm{Kg} / \mathrm{m} 2)\end{array}$ & $\begin{array}{l}19.92 \pm 2.58 \\
(15.22-29.41)\end{array}$ & $\begin{array}{ll}19.52 \pm 1.62 \\
(16.36-23.23)\end{array}$ & 0.64 & $>0.05$ \\
\hline
\end{tabular}

Parenthesis shows range. Serum HDL-C was measured and compared between case and control. Mean \pm SD of HDL-C in case and control were $31.72 \pm 8.99$ and $55.60 \pm 6.81$ respectively. Significant lower value $(\mathrm{p}<0.001)$ was observed in case than control. Serum HDL$\mathrm{C}$ was also measured and compared within the groups of case. Mean \pm SD of HDL-C in group I, II and III were $33.95 \pm 8.77,31.50 \pm 8.22$ and $29.70 \pm 9.84$ respectively. No significant difference $(p>0.05)$ was found among the subgroups. (Table II \& III).

Table-II: Comparison of serum HDL-C in case \& control

\begin{tabular}{|l|l|l|l|}
\hline Grouping & HDL-C (mg/dL) & $\mathrm{t}$ - value & $\mathrm{p}$ value \\
\hline Case $(\mathrm{n}=60)$ & $\begin{array}{l}31.72 \pm 8.99(15- \\
50)\end{array}$ & -10.87 & $<0.001$ \\
\hline Control $(\mathrm{n}=20)$ & $\begin{array}{l}55.60 \pm 6.81(45- \\
67)\end{array}$ & & \\
\hline
\end{tabular}

Parenthesis shows range Unpaired t-test was done

Table-III: Comparison of serum HDL-C among subgroups of case

\begin{tabular}{|l|lr|l|l|}
\hline \multicolumn{2}{|l|}{ Grouping of the cases } & $\begin{array}{l}\text { Mean } \\
\text { differenc }\end{array}$ & p value \\
\hline Group I (n=20) & Group II $(31 \quad .50 \pm 8$. & 2.45 & $>0.05$ \\
\hline$(33.95 \pm 8.77)$ & Group III $(29.70 \quad \pm$ & 4.25 & $>0.05$ \\
\hline Group II $(\mathrm{n}=20)$ & Group I (33.95 \pm 8.77$)$ & -2.45 & $>0.05$ \\
\hline$(31.50 \pm 8.22)$ & Group III $(29 . \quad 70$ & 1.80 & $>0.05$ \\
\hline Group III $(\mathrm{n}=20)$ & Group I (33.95 \pm 8.77$)$ & -4.25 & $>0.05$ \\
\hline$(29.70 \pm 9.84)$ & Group II $(31.50 \pm 8$. & 1.80 & $>0.05$ \\
\hline
\end{tabular}

Bonferroni test was done

Weak negative correlation was observed between serum HDL-C levels with the number of stick consumption per week. (Table IV).

Table-IV: Correlation between serum HDL-C with number of smoking in cases

\begin{tabular}{|l|l|l|l|}
\hline \multicolumn{2}{|l|}{ Variable } & \multirow{2}{*}{ - value } & $\mathrm{p}$-value \\
\cline { 1 - 2 } Independent & Dependent & & \\
\hline Number stick $/$ & HDL-C & -0.273 & $<0.05$ \\
\hline
\end{tabular}

\section{Discussion:}

The aim of the study was to evaluate the effect of smoking on HDL-C, one of the most important cardio protective 
markers, in adolescent and to identify the possible risk factor for development of atherosclerotic changes in early age. We have measured HDL-C in 60 smokers and 20 healthy controls of same socioeconomic class. The plasma HDL-C was found HDL-C with to be significantly lower in cases compared to control. This finding is in line with Morrison et al., Orchard et al., Webber et al., Glueck et at., Halfon, Green and Heiss, Craig et al., and Ghannem et a11.3,5,s, ${ }^{17-19}$.

Comparisons of serum HDL-C among the three subgroups of cases were done. No significant difference was found, though HDL-C values were lower in the group who consumed more number of cigarettes than those who consumed less. We also correlated number of smoking with serum HDL-C in cases which revealed weak negative correlation. These findings partly support the dose response relationship between alterations in HDL-C with number of smoking. Similar results were documented by Muscat, Sirisali and Lee $e^{8,10,11}$. Though Coelho differs with these findings ${ }^{20}$.

From above facts and findings it can be concluded that adolescent smoking might have adverse impact on HDL-C level which may lead to the development of atherosclerotic diseases in the long run and smoking might have causal relation with all sorts of adverse cardivascular events which needs to be explored.

\section{Authors affiliations:}

1. *Dr. Lazina Afrin, Assistant Professor of Physiology, Delta Medical College, Dhaka, Bangladesh.

2. Dr. Md. Rezwanur Rahman, Assistant Professor of Biochemistry, Delta Medical College, Dhaka, Bangladesh.

3. Professor Md. Nazmul Hoque, Head of the Department of Physiology, Shaheed suhrawardy Medical College, Sher-EBanglanagar, Dhaka, Bangladesh.

4. Professor Md. Ruhul Amin, Head of the Department of Physiology, Dhaka Medical College, Dhaka, Bangladesh. * for correspondence

\section{References:}

1. Ghannem H., Harrabi I., Ben Abdelaziz A., Gaha R., Trabelsi L. Smoking habits and cardiovascular risk factors among adolescents in Sousse, Tunisia. Arch Public Health 2003; 61: 151-60.

2. Azevedo A, Machado AP, Baros H. Tobacco smoking among Portuguese high-school students. Bulletin, WHO 1999; 77:6.

3. Glueck CJ, Heiss G, Morrison JA, Khoury P, Moore M. Alcohol intake, cigarette smoking and plasma lipids and lipoproteins in 1219 year children. Circulation 1981;64:48-56.

4. Freedman DS, Srinivasan SR, Shear CL, Hunter SM, Croft JB, Webber LS, Berenson GS. Cigarette smoking initiation and longitudinal changes in serum lipids and lipoproteins in early adulthood: The Bogalusa Heart Study. American Journal of Epidemiology 1986;124(2):207-19.

5. Craig WY, Palomaki GE, Jojnson AM, Haddow JE. Cigarette smoking-associated changes in blood lipid and lipoprotein levels in the 8 to 19 year old age group: A meta analysis. American Academy of Pediatrics 1990;85(2): 155-8.

6. Halfon ST, Green MS, Heiss G. Smoking status and lipid levels in adults of different ethnic origins: The Jerusalem lipid research clinic program. International Journal of Epidemiology 1984;13(2):177-83.

7. Castelli WP. Cholesterol and lipids in the rise of coronary artery disease. The Bramingham Heart Study. Con.J.Cardiol 1988;4A-5A.

8. Muscat JE, Harris RE, Haley NJ, Wynder EL, Columbus. Cigarette Smoking and Plasma Cholesterol. American Heart Journal

9. Fachini FS, Hollenbeck CB, Jeppesen J, Chen YDI, Reaven GDM. Insulin Resistance and Cigarette Smoking. The Lancet. 1992:339:12830.

10. Sirisali K, Poungvarin N, Kanluan T, Prabhant C. Serum Lipid, Lipoprotein-Cholesterol and Apolipoproteins A-l and B of Smoking and Non-Smoking Males. JMed. Assoc Thai 1992:75:709-13.

11. Lee KS, Park CY, Meng KH, Bush A, Lee SH, Lee WC, Koo LW, Chung CK. The Association of Cigarette Smoking and Alcohol Consumption with Other Cardiovascular Risk Factors in Men from Seoul, Korea. Ann Epidemiol 1998;8:31-8.

12. Neki NS, Lipid Profile in Chronic Smokers -A Clinical Study. JIACM2002; 3(1):51-4.

13. Brown JC, Mulligan J, Doyle K, Hagan S, Osmolski T, Hojnacki J. Oral Nicotine Induces An Atherogenic Lipoprotein Profile. Society for Experimental Biology and Medicine 1986:182:409-13.

14. Siegel D, Benowitz N, Ernster VL, Grady DG, Hauck WW. Smokeless Tobacco, Cardiovascular Risk Factors and Nocotine and Cotinine Levels in Professional Baseball Players. American Journal of Public Health 1992:82:417-21.

15. Gordon T, Castelli WP, Hjortland MC. Kannel WB, Dawber TR. High Density Lipoprotein As a Protective Factor Against Coronary Heart Disease. The American Journal of Medicine 1 977:62:707-1 3.

16. Kavey REW. Hypercholesterolemia in Children. American Family Physician 2000; 61(3):1-9.

17. Morrison JA, Kelly K, Mellies M, Groot ID, Khoury P, Gartside PS, Glueck CJ. Cigarette smoking, alchol intake and oral contraceptives: relationships to lipids and lipoproteins in adolescent school children. Metabolism 1979;28(11):1166-70.

18. Orchard TJ, Rodgers M, Hedley AJ, Mitchell JRA. Changes in blood lipids and blood pressure during adolescence. British Medical Journal 1980:1563-7.

19. Webber LS, Hunter SM, Baugh JG, Srinivasan RS, Sklov MC, Berenson GS. The interaction of cigarette smoking, oral contraceptive use, and cardiovascular risk factor variables in children: The Bogalusa Heart Study. Am J Public Health 1982:72:266-74.

20. Coelho VG; Caetano LF; Junior RDRL; Corderio JA; Souza DRS. Lipid profile and risk factors for cardiovascular diseases in medicine students. Arq. Bras. Cardiol 2005; 85:1-13. 